\title{
Optimization of Mud Hammer Drilling Performance - A Program to Benchmark the Viability of Advanced Mud Hammer Drilling
}

Quarterly Progress Report

Reporting Period Start Date - April 1, 2001

Reporting Period End Date - June 30, 2001

Authors; Gordon Tibbitts, TerraTek

Arnis Judzis, TerraTek

Report Date - July, 2001

DOE Award Number - DE-FC26-00NT40918

TerraTek, Inc.

400 Wakara Way

Salt Lake City, UT 84108 


\section{DISCLAIMER}

This report was prepared an as account of work sponsored by an agency of the United States Government. Neither the United States Government nor any agency thereof, nor any of their employees, makes any warranty, express or implied, or assumes any legal liability or responsibility for the accuracy, completeness, or usefulness of any information, apparatus, product, or process disclosed, or represents that its use would not infringe privately owned rights. Reference herein to any specific commercial product, process, or service by trade name, trademark, manufacturer, or otherwise does not necessarily constitute or imply its endorsement, recommendation, or favoring by the United States Government or any agency thereof. The views and opinions of authors expressed herein do not necessarily state or reflect those of the United States Government or any agency thereof. 


\begin{abstract}
This document details the progress to date on the OPTIMIZATION OF MUD HAMMER DRILLING PERFORMANCE - A PROGRAM TO BENCHMARK THE VIABILITY OF ADVANCED MUD HAMMER DRILLING contract for the quarter starting April 2001 through June 2001.
\end{abstract}

Accomplishments to date include the following:

- DOE's National Energy Technology Laboratory highlighted the Mud Hammer Project at an exhibit at the Offshore Technology Conference April 30 through May 3. TerraTek assisted NETL personnel with presentation materials appropriate for the project and a demonstration sample of 'hard rock' drilled in TerraTek's wellbore simulator.

- TerraTek has completed 13 drilling tests in Carthage Marble and hard Crab Orchard Sandstone with the SDS Digger Tool, Novatek tool, and a conventional rock bit. After some initial mud pump and flow line problems at TerraTek, we completed the testing matrix for the SDS Digger Tool and the Novatek hammer on 27 June 2001. Overall the hammers functioned properly at 'borehole' pressures up to 3,000 psi with weighted water based mud. The Department of Energy goals to determine hammer benchmark rates of penetration and ability to function at depth are being met. Additionally data on drilling intervals and rates of penetration specific to flow rates, pressure drops, rotary speed, and weights-on-bit have been given to the Industry Partners for detailed analysis. SDS and Novatek have gained considerable experience on the operation of their tools at simulated depth conditions. Some optimization has already started and has been identified as a result of these first tests. 


\section{TABLE OF CONTENTS}

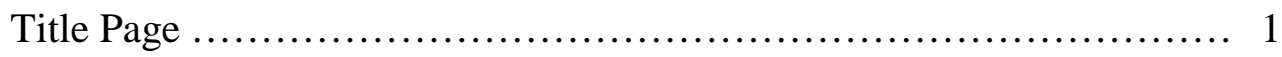

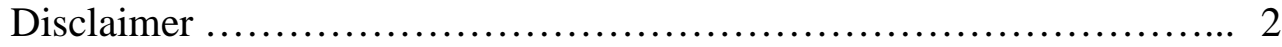

Abstract ............................................................. 3

Table of Contents .................................................. 4

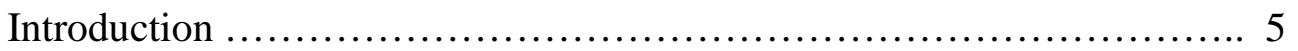

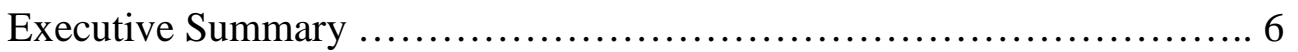

Experimental ...................................................... 7

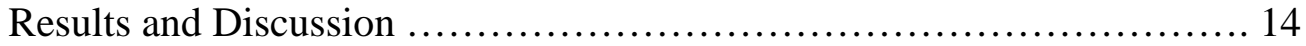

Conclusions ..................................................... 15

References ....................................................... 15 


\section{INTRODUCTION}

The Department of Energy's role in various drilling projects was demonstrated at the Offshore Technology Conference exhibit April 30 through May 3, 2001 in Houston. The following information was provided by TerraTek and exemplifies the nature of the 'Mud Hammer' project work.

\section{WORLD'S FIRST MUDHAMMER COMPARATIVE TESTING AT TERRATEK}

- Mudhammer Testing for Deep, Hard Rock

- Multiple Simulated Depths

- Multiple Hard Rocks

- Drilling Hammers Evaluated Novatek SDS Digger

- Testing Start Date May, 2001

- Two Year Program

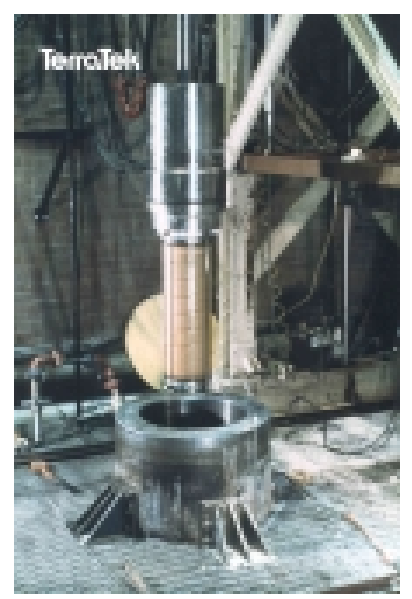




\section{EXECUTIVE SUMMARY}

Progress on Phase 1 (US Government Fiscal Year '01) work on the testing of fluid driven drilling hammers is encouraging and on track.

Background - On January $9^{\text {th }}$ of 2001, details of the Mud Hammer Drilling Performance Testing Project were presented at a "kick off" meeting held in Morgantown. Industry support is high and the importance to the drilling industry, as the business challenge of "hard rock drilling", was presented by John Shaughnssy of BP Amoco. The Industry Partners for this program are SDS Digger Tools, Novatek, BP Amoco, and ExxonMobil. A test program was formulated and prepared for presentation at a meeting of the Industry Advisory Board in Houston on the $8^{\text {th }}$ of February. The meeting was held and the DOE approved a test program was after thorough discussion.

DOE's National Energy Technology Laboratory highlighted the Mud Hammer Project at an exhibit at the Offshore Technology Conference April 30 through May 3. TerraTek assisted NETL personnel with presentation materials appropriate for the project and a demonstration sample of 'hard rock' drilled in TerraTek's wellbore simulator.

TerraTek has now completed 13 drilling tests in Carthage Marble and hard Crab Orchard Sandstone with the SDS Digger Tool, Novatek tool, and a conventional rock bit. After some initial mud pump and flow line problems at TerraTek, we completed the testing matrix for the SDS Digger Tool and the Novatek hammer on 27 June 2001. Overall the hammers are functioned properly at 'borehole' pressures up to 3,000 psi with weighted water based mud. Clearly the Department of Energy goals to determine hammer benchmark rates of penetration and ability to function at depth are being met. Additionally data on drilling intervals and rates of penetration specific to flow rates, pressure drops, rotary speed, and weights-on-bit have been given to the Industry Partners for detailed analysis. SDS and Novatek have gained considerable experience on the operation of their tools at simulated depth conditions. Some optimization has already started and has been identified as a result of these first tests. For example, SDS Digger's use of a more aggressive bit during one benchmarking trial in $15 \mathrm{ppg}$ mud improved performance. The DOE has an another goal; ie. To accelerate the commercialization of mud hammers and to make them available to operators. Through learning gained from these initial tests, these hammers will become available faster.

Based on the current success of the mud hammer performance benchmarking trials, we will proceeding to the DOE's program tasks to 'optimize' mud hammer performance. This will allow SDS Digger and Novatek to make tool modifications, improvements as needed, and perform drilling tests at TerraTek for applications specific to their application areas. This will most likely start after September 2001. BP Amoco and ExxonMobil have gained much information about the hammer tools also; they view field trials as an important next step to the 'benchmarking' and 'optimization' trials at TerraTek. 


\section{EXPERIMENTAL}

Background - from previous quarterly report

\section{TEST SEQUENCE}

$\begin{array}{lllr}\text { TEST } & \text { HAMMER/BIT } & \text { ROCK } & \text { MUD DENSITY } \\ 1 & \text { SDS } & \text { Carthage Marble } & 10 \mathrm{ppg} \\ 2 & \text { SDS } & \text { Crab Orchard S.S. } & 10 \mathrm{ppg} \\ 3 & \text { Novatek } & \text { Carthage Marble } & 10 \mathrm{ppg} \\ 4 & \text { Novatek } & \text { Crab Orchard S.S. } & 10 \mathrm{ppg} \\ 5 & \text { Conventional } & \text { Carthage Marble } & 15 \mathrm{ppg} \\ 6 & \text { Conventional } & \text { Crab Orchard S.S. } & 15 \mathrm{ppg} \\ 7 & \text { SDS } & \text { Carthage Marble } & 15 \mathrm{ppg} \\ 8 & \text { SDS } & \text { Crab Orchard S.S. } & 15 \mathrm{ppg} \\ 9 & \text { Novatek } & \text { Carthage Marble } & 15 \mathrm{ppg} \\ 10 & \text { Novatek } & \text { Crab Orchard S.S. } & 15 \mathrm{ppg} \\ 11^{* *} & \text { SDS } & \text { Carthage Marble } & 15 \mathrm{ppg} \\ 12^{* *} & \text { SDS } & \text { Crab Orchard S.S. } & 15 \mathrm{ppg} \\ 13 * * & \text { Novatek } & \text { Carthage Marble } & 15 \mathrm{ppg} \\ 14 * * & \text { Novatek } & \text { Crab Orchard S.S. } & 15 \mathrm{ppg} \\ * \text { Use the data from SPE paper No. } & \text { 15620 for conventional bit performance (HPSM } \\ \text { rollercone bit) in 10ppg mud. } & \end{array}$

Testing configurations for both the SDS and Novatek hammers were reported last quarter. Owing to the early equipment problems experienced by Novatek (nozzles, bit washout) and to a lesser extent SDS, some of the experiments were started and stopped numerous times, thus adding to set-up, changeover, and waiting on equipment times. Nonetheless, the test matrix was completed under DOE's guidance as follows (multiple tests with letter designations indicate performance interval data was taken at different times and on separate files due to interruptions, hammer modifications, etc. The exception is test \#3 where a change out to a different bit was made):

1. DOE 1 ( plus $1 \mathrm{~A} \& 1 \mathrm{~B})$

2. DOE 2 (plus 2A \& 2B)

3. DOE 3, Novatek bit

4. DOE 3A, roller cone bit

5. DOE 4

6. DOE 5

7. DOE 6 (plus 6A)

8. DOE 7

9. DOE 8 (plus 8A \& 8B)

10. DOE 9

11. DOE 10

12. DOE 11 (plus 11A)

13. DOE 12
SDS

SDS

Novatek

Novatek

Conventional

Conventional

SDS

SDS

SDS

SDS

Novatek

Novatek

Novatek 
Summary data for these tests follow:

Comparison of DOE Test 1 SDS FH185 Hammer/Hard Formation Bit and 8 1/2" Reed HPSM Bit Rotary Drilling for 10 ppg Water-base Mud and Carthage Marble

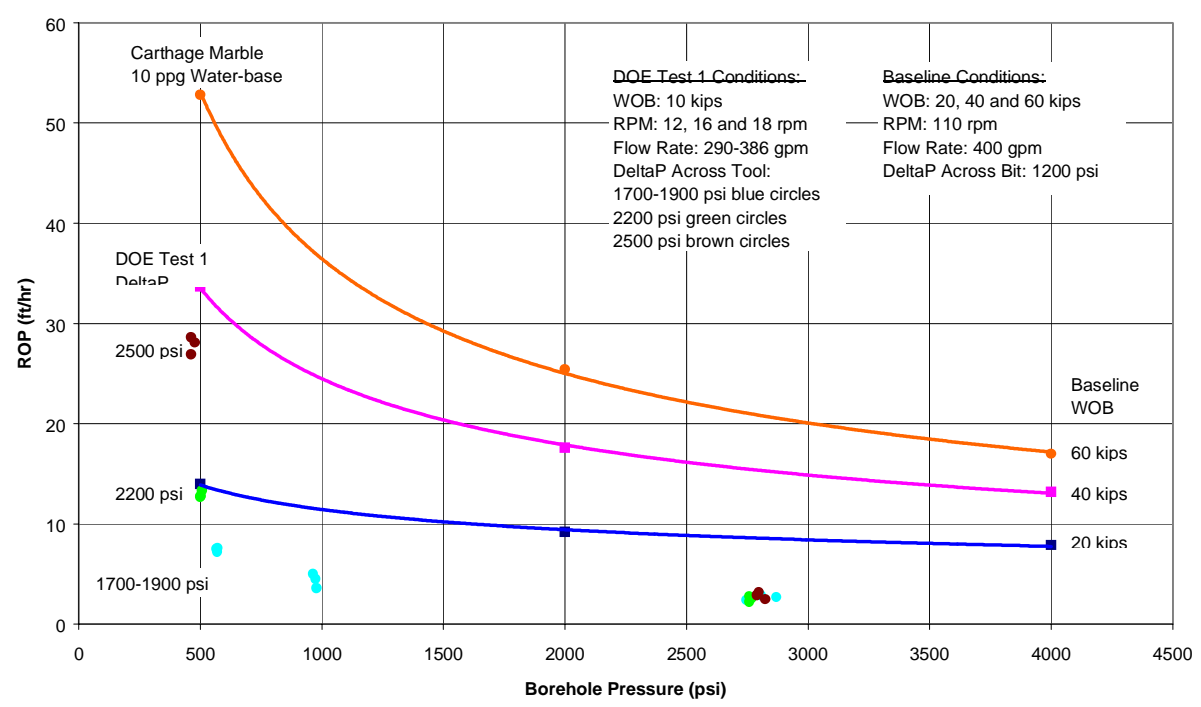

Comparison of DOE Test 2 SDS FH185 Hammer/Hard Formation Bit and 8 1/2" Reed HPSM Bit Rotary Drilling for 10 ppg Water-base Mud and Crab Orchard Sandstone

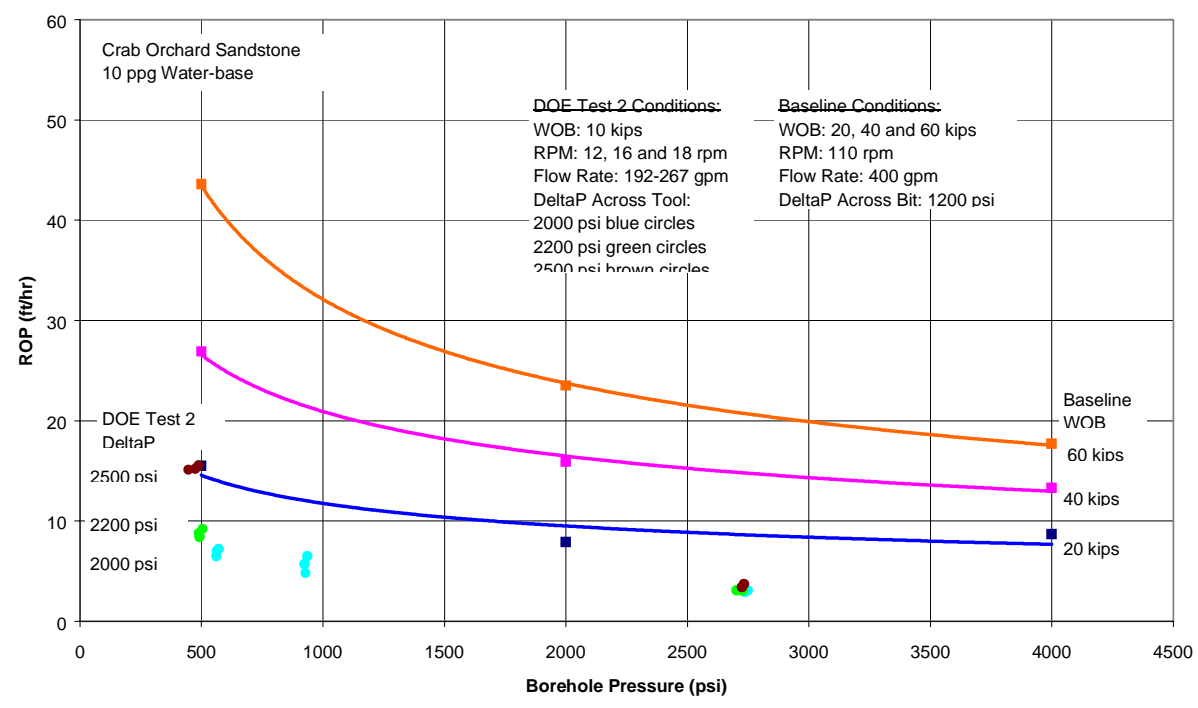




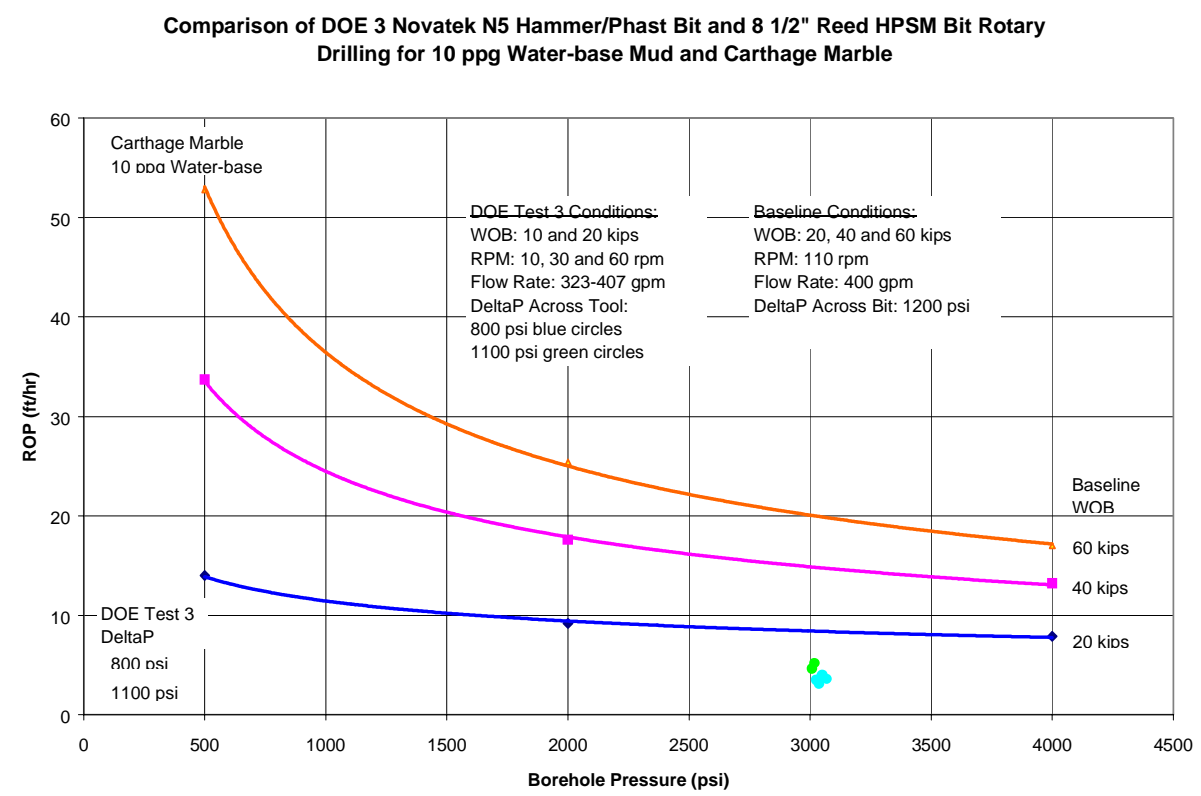

Comparison of DOE 3A Novatek N5 Hammer/Reed HPSM Bit and 8 1/2" Reed HPSM Bit Rotary Drilling for 10 ppg Water-base Mud and Carthage Marble

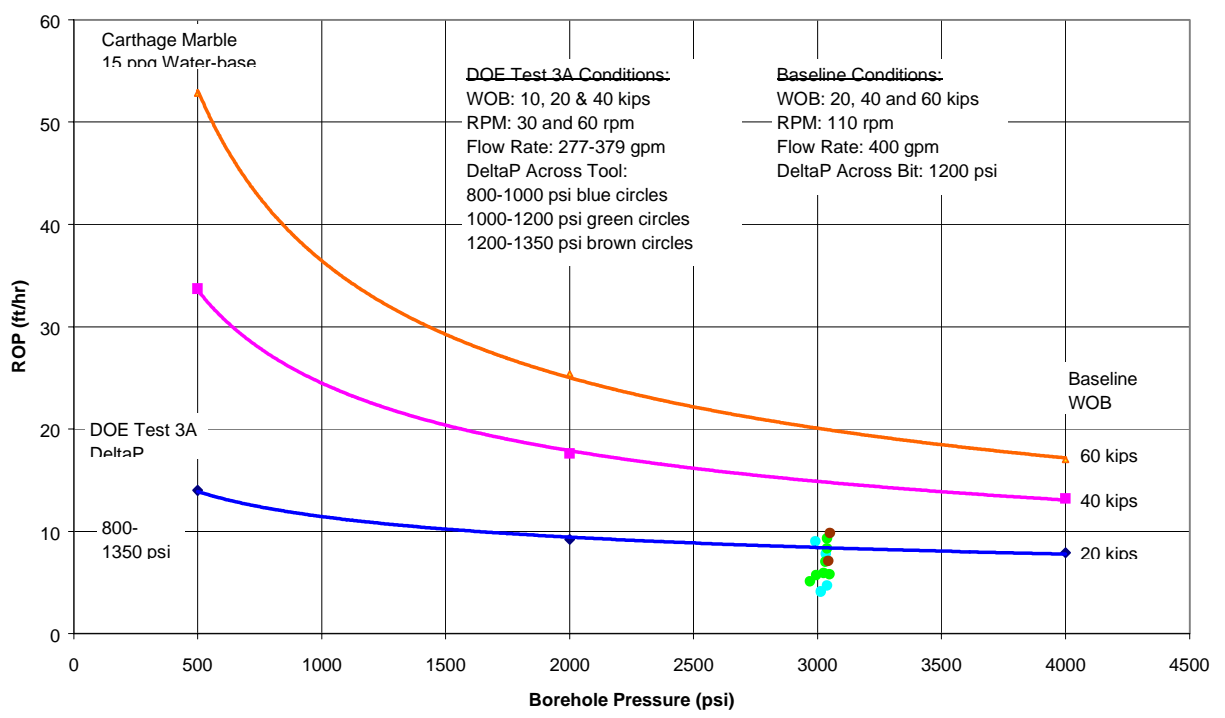




\section{DOE 4}

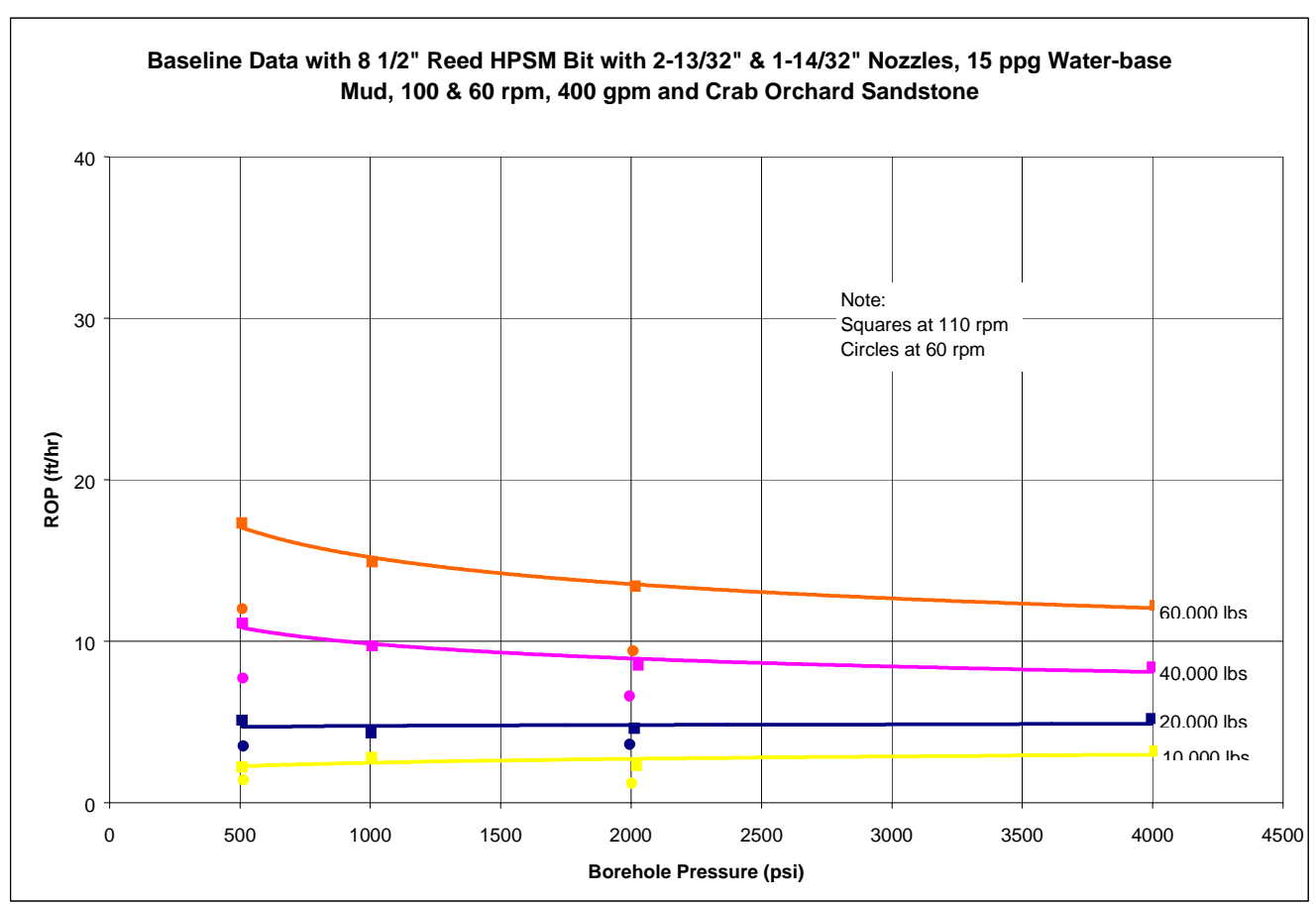

\section{DOE 5}

Baseline Data with 8 1/2" Reed HPSM Bit with 2-13/32" \& 1-14/32", 15 ppg Water-base Mud, 110 \& 60 rpm, 400 gpm and Carthage Marble

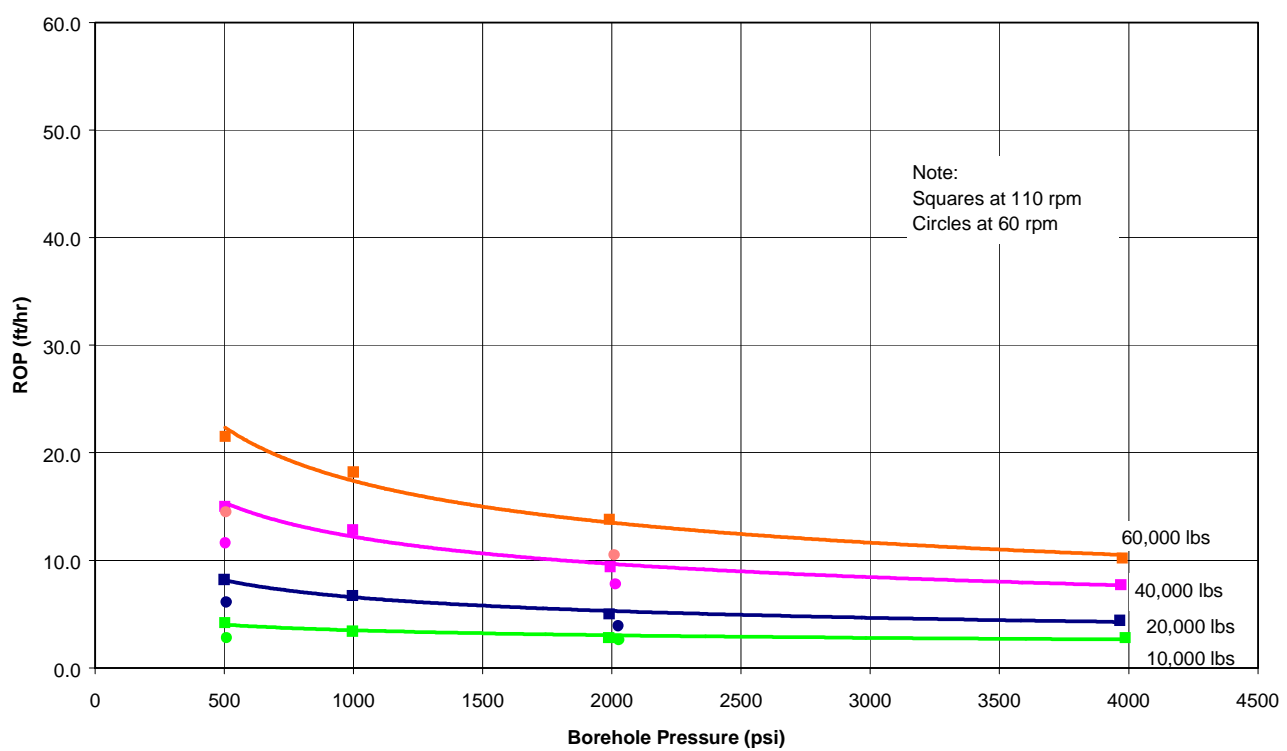




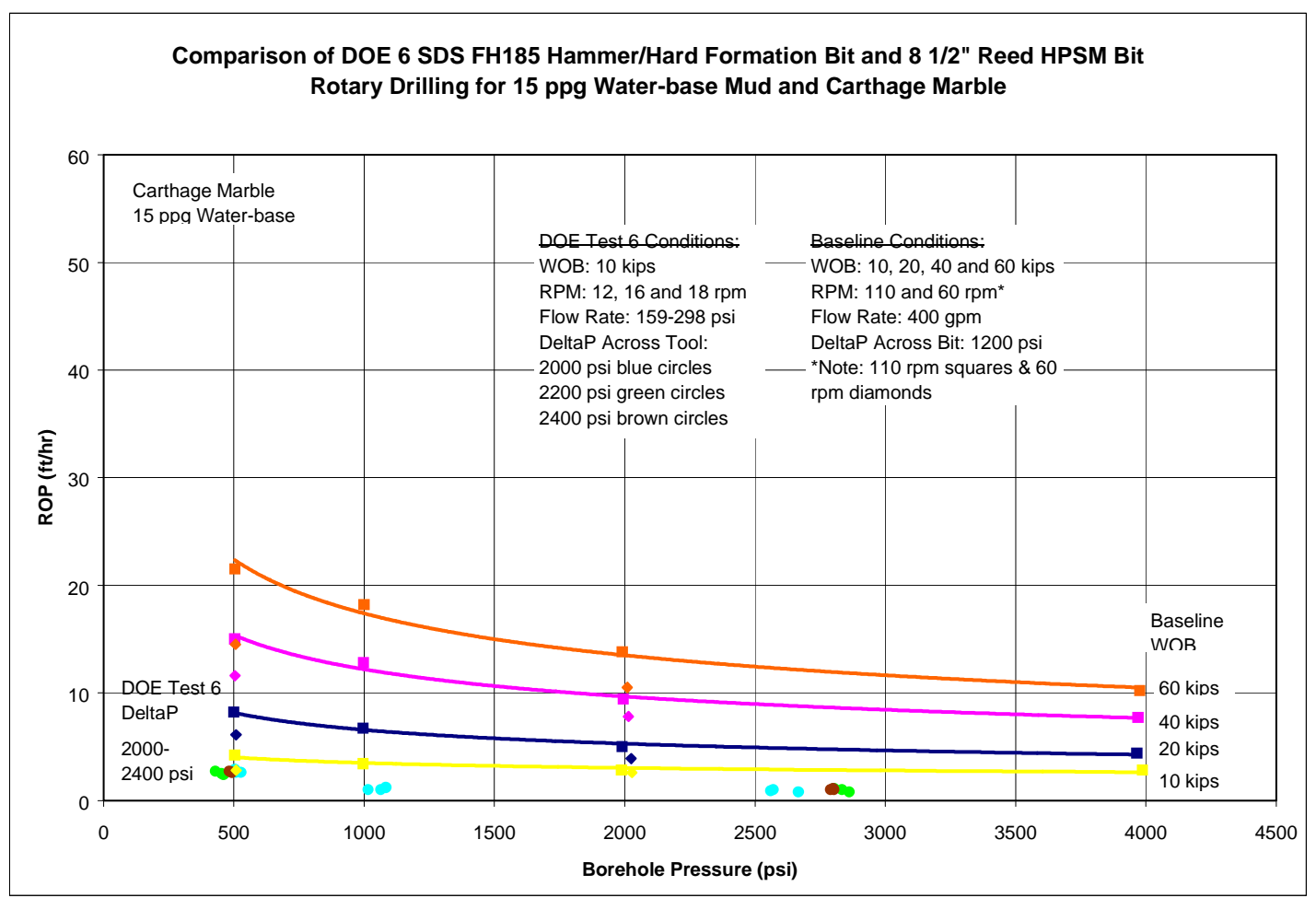

Comparison of DOE 7 SDS FH185 Hammer/Hard Formation Bit and 8 1/2" Reed HPSM Bit Rotary Drilling for 15 ppg Water-base Mud and Crab Orchard Sandstone

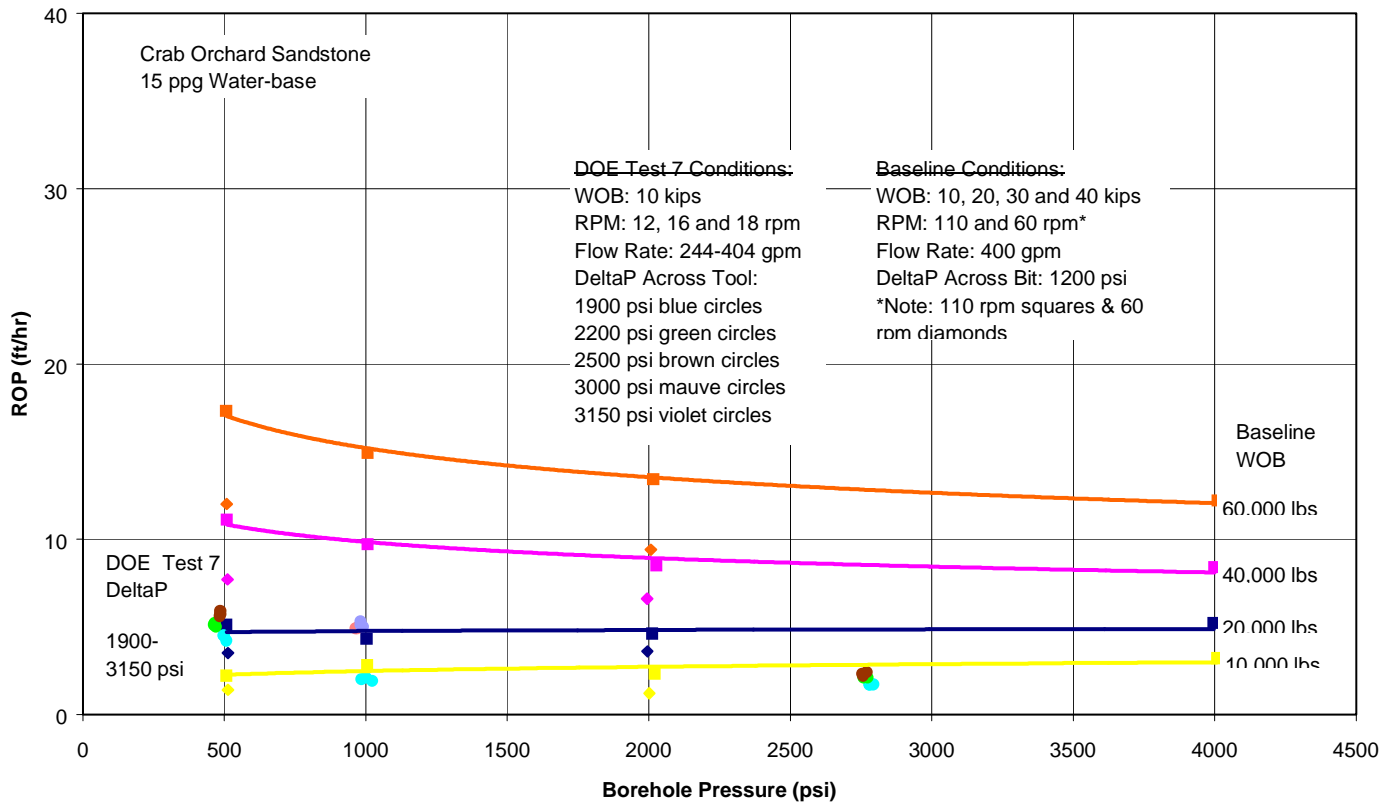


Comparison of DOE 8 SDS FH185 Hammer/Soft Formation Bit and 8 1/2" Reed HPSM Bit Rotary Drilling for 15 ppg Water-base Mud and Carthage Marble

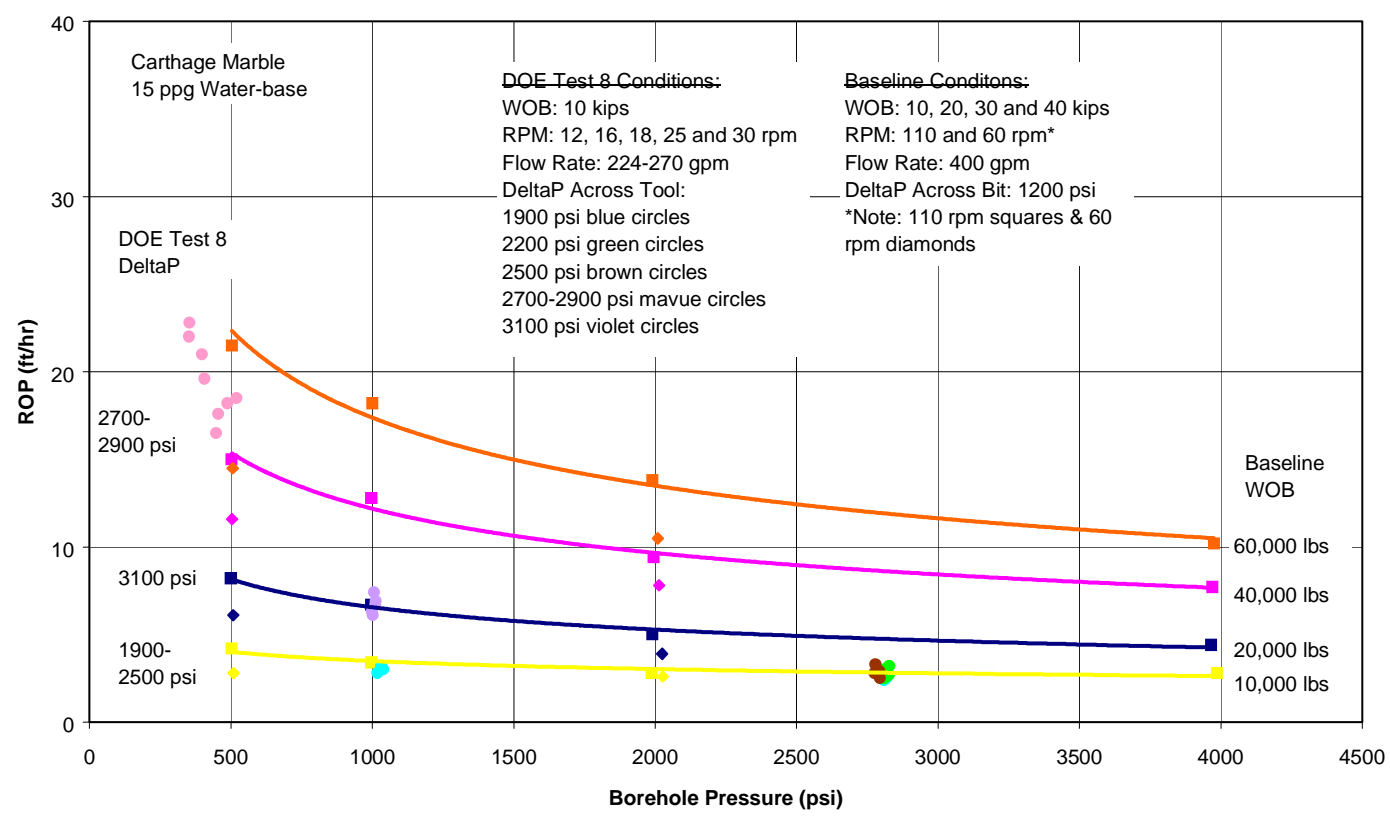

Comparison of DOE 9 SDS FH185 Hammer/Soft Formation Bit and 8 1/2" Reed HPSM Bit Rotary Drilling for 15 ppg Water-base Mud and Crab Orchard Sandstone

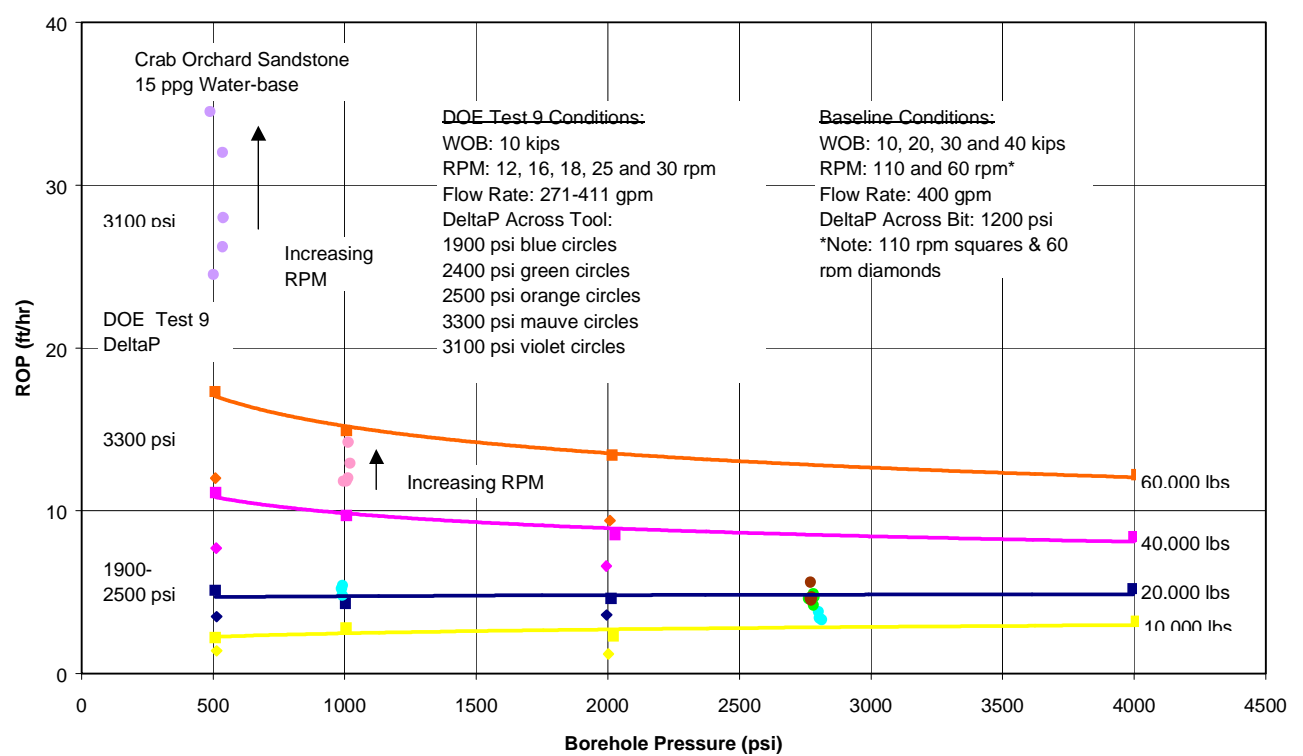




\section{Comparison of DOE 10 Novatek N5 Hammer/Phast Bit and 8 1/2" Reed HPSM Bit Rotary Drilling for 15 ppg Water-base Mud and Carthage Marble}
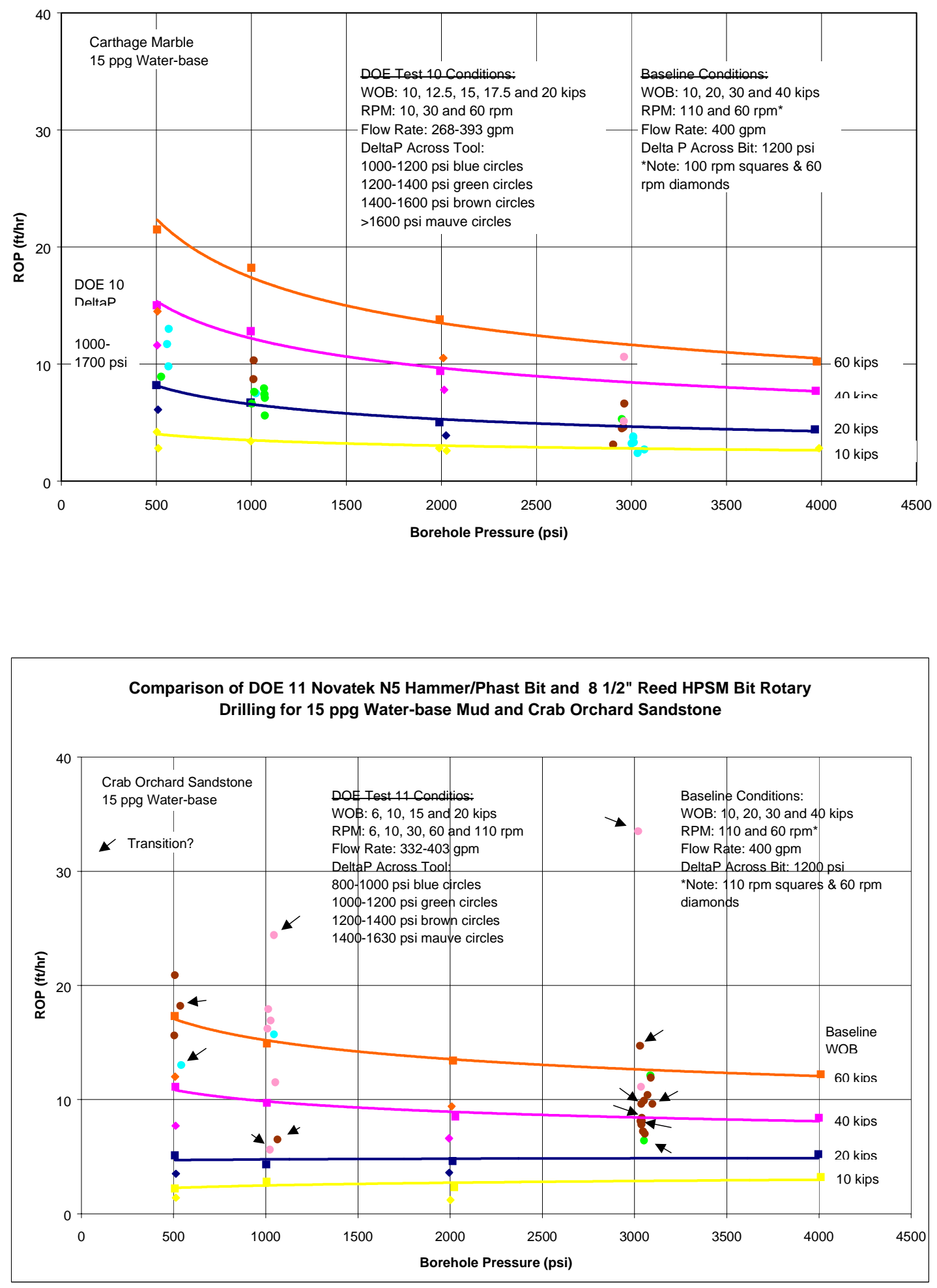
Comparison of DOE 12 Novatek N5 Hammer/Phast Bit and 8 1/2" Reed HPSM Bit Rotary Drilling for 15 ppg Water-base Mud and Carthage Marble

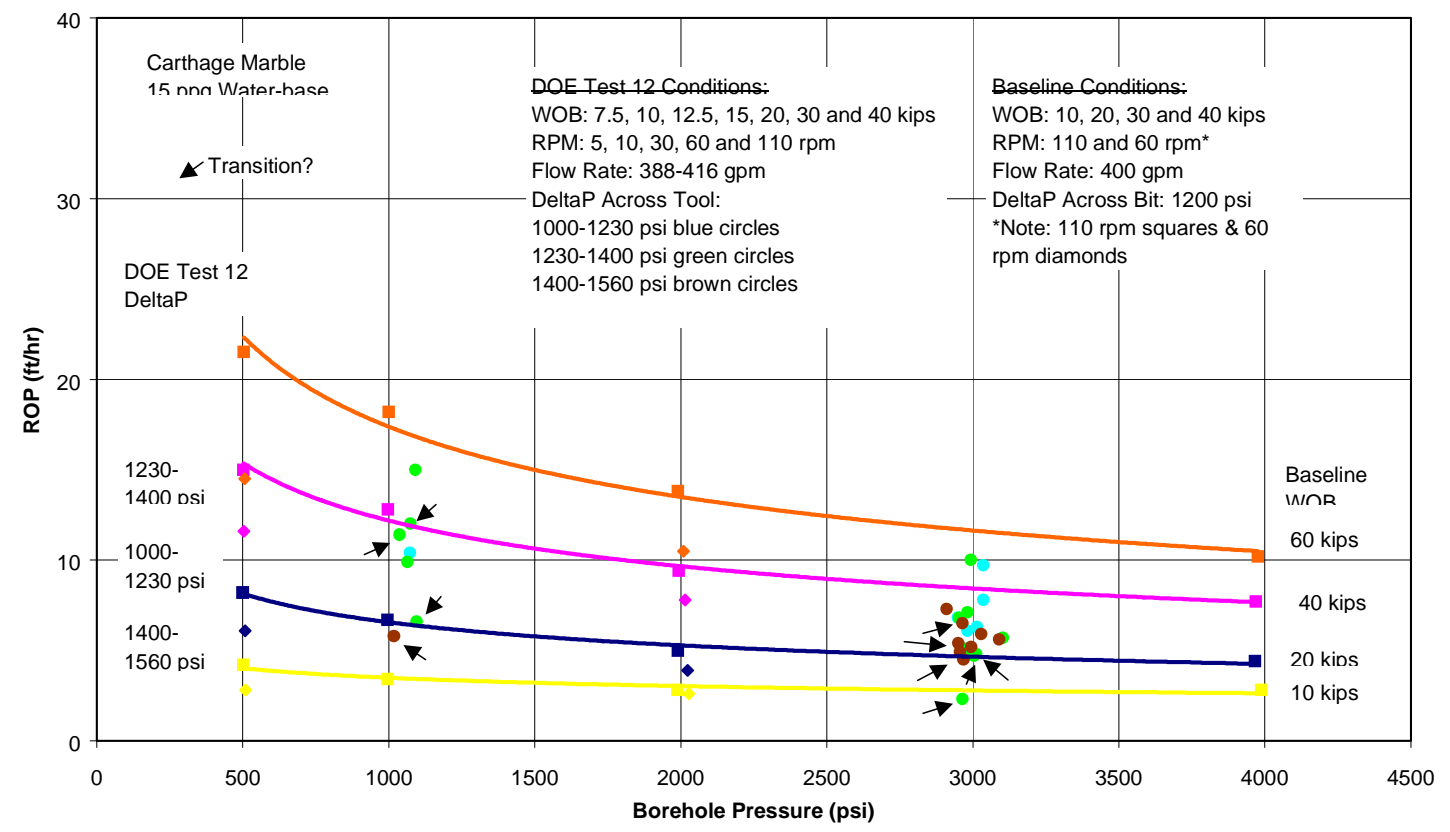

\section{RESULTS AND DISCUSSION}

After kicking off the project beginning January, 2001 progress has been made according to the schedule and scope of work proposed. Tasks 1, 2, and 3 have been completed, with progress now being made on Task 4 and 5 (complete analysis of data and conduct 'lessons learned' meeting with Industry Sponsors).

Review of January 2001 through March 2001 -

Task 1 - As confirmed by Roy Long, COR at NETL, the information required for the National Environmental Policy Act was submitted in calendar year 2000.

Task 2 - Completed and described in previous quarterly report.

Task 3 - Prepared rock samples and finalized tool logistics with hammer suppliers. 
Review of April 2001 through June 2001 -

Task 3 - Set-up of large scale experiments completed. The test program was completed on June 27, 2001 after 13 full-scale tests were completed. Initial flow line and mud pump problems were resolved at TerraTek. The Novatek bit experienced both washouts and nozzle failures at first. The bit was repaired and testing continued after some delay and extra set-up time.

Task 4 - Benchmarking of mud hammer performance is $80 \%$ complete. Interval data from all tests has been transmitted to the DOE project manager and Industry Sponsors. Final plotting and summary of performance results are underway.

Task 5 - A Peer Review ('Lessons Learned' meeting) will be held with all participants. The suppliers will review their own learnings and progress in addressing performance problems.

\section{CONCLUSIONS}

- The project is on schedule with the same scope of work

- Industry interest in the project is increasing. TerraTek has had inquiries from Statoil, Andergauge, Schlumberger, and PDVSA about 'joining' the consortium program. Any additional testing by Industry Sponsors would effectively increase industry cost sharing. Review articles exemplified by Petrobras (reference 1) are increasing industry awareness of the business need to improve hard rock drilling performance.

- Industry interest in determining 'energy into the rock' relationships for the hammers is also growing. Effort is underway to define an Industry Sponsor program for additional measurements.

- Tasks 1,2, and 3 are completed.

- Task 4 is $80 \%$ completed.

\section{REFERENCES}

1. Santos, H., Placido, J., Oliveira, J., and Gamboa, L., "Overcoming Hard Rock Drilling Challenges", IADC/SPE Paper 59182 presented at the 2000 IADC/SPE Drilling Conference held in New Orleans, Louisiana, 23-25 February 2000. 